\title{
A bibliometric analysis of the scientific literature on Fairtrade labelling
}

\begin{abstract}
Since its foundation, the Fairtrade movement has attracted the attention of consumers, practitioners, media and scholars. Discussing the role that Fairtrade can play on a global yet locally rooted scale is very complex, as research reports contrasting results about its usefulness and effectiveness. This study examines scientific research on Fairtrade over the last decades by conducting a bibliometric analysis of the literature published on the ISI Web of Knowledge Core Collection, which included 876 papers by 1293 authors in 432 journals. Results show that despite this is a relatively recent field of study, Fairtrade has been approached from different disciplines with different methodologies and objectives. The structured quantitative study of the literature enabled us to inspect how research has evolved over the years in the light of the changes faced by Fairtrade, to explore its scope in the broader field of global market, to detect current research schools and perspectives within the network and to push the envelope by identifying hither to unaddressed issues and unconnected subfields.
\end{abstract}

Keywords: Fairtrade, Fair Trade, Co-citation analysis, Bibliographic coupling 


\section{Introduction}

Fairtrade (FT) is a product certification and labeling system that seeks consumers' recognition through quality labels and public and/or private certification (Renard, 2005), by standardizing and unveiling the conditions of production (Naylor, 2014). The concept that underlies the FT certification is quite simple: relying on consumers' willingness to pay for products with a higher ethical content, FT imposes more equitable conditions of production and trade over certified products, in order to improve working conditions and empower small farmers and hired laborers.

Nowadays, FT encompasses 1.65 million farmers and workers, organized in more than 1200 producer's organizations, spread across 74 countries worldwide, producing goods that are sold in over 125 countries through different types of distribution channel (Fairtrade International, 2015). There are over 30,000 FT certified products on sale worldwide and there are standards for both food and non-food products.

Although the true significance of FT might not lie in its market share but in its ability to create new links between producers in the south and consumers in the north (Low \& Davenport, 2005; Raynolds, 2000, 2002), FT sells grew by $27 \%$ in $2009-2010,21 \%$ in the following two years and $15 \%$ in 2012-2013, passing from a total turnover of 3.4 billion $€$ in 2009 to 5.5 billion $€$ in 2013 (Fairtrade International, 2012, 2015). In 2015 FT global sales reached $€ 7.3$ Billion (Fairtrade International, 2016a). Most of the sales are concentrated in the US, UK and Germany but many new markets are expanding rapidly and have already achieved significant sales (Fairtrade International, 2014).

One of the most interesting aspects that stand out when it comes to Fair Trade is certainly the dynamism that has characterized this movement from its birth until the present day, and the strategies that the movement has adopted to respond to the changing conditions of global exchange over the years (Jaffee, 2007; Reed, 2009; Shreck, 2005). Nevertheless, FT success and growth worldwide has depended primarily on two turning points: the introduction of formal labeling initiatives, launched in Europe in 1988 (Bacon, 2010; Doherty et al., 2013; Raynolds, 2002; Renard, 2005), and the 
increasing involvement of corporations in FT, in what has been described as a mainstream strategy, during the 1990s.

Since then, the FT label can be found on the packaging of products produced by large multinationals sold in supermarket chains as well as on productions performed on a small scale and sold through alternative shops or dedicated mail order (Doherty et al., 2013; Méndez et al., 2010; Reed, 2009) (Moore, 2015).

Fairtrade (FT) is not a new subject in academic literature: starting from the eighties it has attracted attention of scholars from a wide range of disciplines, including economics, marketing, design, agriculture, rural studies, development studies and theology (Moore, 2004).

On the basis of the large bibliography of scientific researches that have analyzed FT over the years in which the movement has developed and evolved, a structured quantitative study of the literature can help (i) to explore the scope of the FT in the broader field of global market over time, (ii) to detect the most influential articles that have been at the base of the research, (iii) to detect current research schools and perspectives within the FT and (iii) to identify unaddressed issues and unconnected subfields. Accomplishing these goals will substantiate evidence from field studies and literature reviews of the FT and help cross-validate their findings and assessments.

Although there have been several reviews dedicated to the topic of FT, none of them provides a comprehensive analysis of the FT scientific literature through bibliometric tools. Furthermore, previous reviews focus only on research on specific aspects at once, rather than addressing the research in its entirety. For example, Andorfer and Liebe (2012), Grankvist (2012), Lyon (2006), and Nicholls and Opal (2005) analyzed research on FT consumption; while Parvathi and Waibel (2013), Terstappen et al. (2013), Gibbon and Śliwa (2012), Blowfield (2010), Nelson and Pound (2009), and Le Mare (2008) focused on studies on social and economic development of producers.

The present paper attempts to analyze and critically appraise the literature on FT by means of the methodologies and instruments provided by bibliometrics. Our analysis makes an important contribution for scholars interested in the study of FT, as it provides a quick reference guide for 
interdisciplinary researchers as well as marketers who want to know how the fair trade movement has been addressed by scientific research over the years. We identify the main countries, institutes, journals, authors and articles in this research area, and we outline the structure of research on FT over time, synthetizing the main streams.

\section{Method}

\subsection{Bibliometric analysis}

The methods followed in this paper are rooted in bibliometrics (De Solla Price, 1965; Garfield, 1955; Small, 1973) which consists in a set of methods that can be employed to evaluate research through statistical analysis of bibliographic data, commonly focusing on citation analysis of research outputs and publications. Bibliometric comprehends two main categories of analysis: performance analysis and science mapping (Moed et al., 2005; Noyons et al., 1999; VanEck \& Waltman, 2014). The first category aims at evaluating actors (mainly authors, institutes, journals and countries) on the basis of bibliographic data. The second category, science mapping, is a spatial representation of bibliometric networks to explore the interrelation between disciplines, fields, specialties, individual papers or authors. There are several bibliometric techniques that have been developed over time to build a science map (Small, 2006), the most commonly used being documents co-citation and bibliographic coupling analysis (Cobo et al., 2011). In bibliometric, citation counts are assumed to generally reflect the resonance of a paper in the scholarly community in an objective and measurable way.

Co-citation analysis (Marshakova, 1973; Small, 1973; Small \& Crane, 1979; Small \& Griffith, 1974) is a bibliometric technique proposed by Small (1973) that aims to map the structure of a research field through the analysis of groups of documents that are commonly cited together (Cobo et al., 2011). Two documents are said to be co-cited when they both appear in the reference list of a third document; the more papers they are both cited by, the stronger their association. The major 
drawback of co-citation analysis is regarded as an approach biased towards 'the past' of an academic field, as it is more likely to capture older contributions and well established scholars rather than the forefront of the research (López-Fernández et al., 2016; VanEck et al., 2013). Not surprisingly, this technique is used to provide a comprehensive historical view of the intellectual structure of a specific field of study. The co-cited papers in each clusters tend to share some common themes and they are considered to represent the core knowledge base of a research area: the key concepts, methods, or experiments that researchers build on (Small, 1980). Co-citation analysis allows the exploration of dynamics of scientific development and conceptual shifts of a specific subject (Small, 1973).

Bibliographic coupling can be interpreted as the opposite process of co-citation: two publications are said to be bibliographically coupled if there is a third publication that is cited by both publications (Glänzel \& Czerwon, 1996; Jarneving, 2007; Vladutz \& Cook, 1984). The larger the number of references two publications have in common, the stronger the bibliographic coupling relation between the publications is (Eck \& Waltman, 2014). Bibliographic coupling is about the overlap in the reference lists of publications, thus focusing on the association between two citing publications (Eck \& Waltman, 2014). One advantage of bibliographic coupling compared to the cocitation analysis is the absence of restrictions on frequently cited papers. Therefore, the results of bibliographic coupling do not depend on the moment in which the data are collected, and since documents that includes citations are more recent than the documents they cite, this method is suitable to investigate more recent contributions.

Since our intention is to focus on both past and present research, we have chosen to jointly apply co-citation and bibliographic coupling on the body of scientific literature dealing with FT, in order to combine the insights provided by the two techniques. Both co-cited and coupling linked articles are assumed to form groups of publications that represent the same or at least related research topics, and both techniques aim to detect groups of publications that share common intellectual background. 
The co-citation procedure is constructed as follows. From the reference lists of the set of publications, documents that are cited more than a specified threshold are coupled according to how frequently the pair co-occur in the reference lists. Conversely, documents that share more than a specified threshold of references are selected to construct the Bibliographic coupling network, where the number of shared references represents the coupling strength between them. After the normalized networks have been computed, the next step is to position the nodes in a two-dimensional space in such a way that strongly related nodes are located close to each other, while weakly related nodes are located far away from each other. Documents skimming, the extraction of the cited literature, and the creation of the co-citation and coupling matrix of references were computed through the software Bibexcel, and then processed in the software VOSviewer for mapping and clustering. Starting from a correlation matrix, Vosviewer constructs the map by calculating a similarity matrix based on the co-occurrence matrix, then the VOS mapping technique is applied to the similarity matrix. The criteria used by VOS is to minimize the weighted sum of the squared distances between all pairs of publications, weighted by the similarity between them (VanEck \& Waltman, 2010). The VOS mapping technique locate publications in a low-dimensional space in which the distance between any two items reflects the similarity or relatedness, then cited documents are aggregated in clusters by sequentially linking together all selected pairs of cited documents. These clusters represent the intellectual base of the different subfields of research.

\subsection{Searching strategy}

The bibliographical data gathered in this study was collected from Thomson Reuters' ISI Web of Science Core Collection, through the search of the terms "fairtrade" and/or "fair trade" in the field Topic, which contains titles, abstract and keywords. The choice to use quotes in the search is motivated by the different meanings that the two terms "Fair" and "Trade" may assume when taken individually (e.g. trade fairs). Another factor that may affect the data is given by the Wos Keyword 
Plus, which are based on the bibliography and automatically generated through an algorithm and therefore may be inconsistent with the terms of the search (Garfield \& Sher, 1993). For these reason, coherence with the subject matter of the resulting 1162 portfolio of papers has been verified by reading the titles, and in some cases the abstract and the articles as well. Through this process, 286 documents have been removed from the database, leading to a final dataset of 876 documents.

\subsection{Data}

Table 1 and Figure 1 present several characteristics of the FT publications between 1985 and 2015. The study of the number of publications and authors reveals the growing interest in this subject. In more detail, FT has become a real subject of studies from the year 2005: even though the earlier documents are dated back to 1985. From 2005, all these parameters show a growing trend that culminates with a maximum reached in 2010; from the following year it is noticed a short slowdown, immediately followed by a steady increase over the following five years that lasts until today.

It is worth noting that the increase of FT-related publications from 2005 coincides with the end of a period of radical changes in the coffee market, which still represents the most important fair-labeled product both in terms of sales volume and number of countries involved. Keeping in view this temporal distribution of scientific production on FT, Figure 1 also shows that the most cited works are concentrated in a time span ranging from 2004 to 2010.

$$
\begin{aligned}
& \text {---insert Figure } 1 \text { here ---- } \\
& \text {--- insert Table1 here ---- }
\end{aligned}
$$

\section{Results}

This section discusses the findings of the quantitative analysis of the articles that compose the database.

\subsection{Mapping}


Since 1985 to 2014, Universities from 72 countries have contributed to FT research: the USA have always played a dominant role with almost $25 \%$ of the total publications, followed by UK (17\%), Canada (6\%), France (6\%), Netherlands (5\%) and Germany (4\%). The 15 most productive countries and institutions are displayed in Table 2. The leading position of USA and UK in FT literature is also evident through the analysis of the most active institutions and organizations: among the top 20 most productive institutions the USA occupy the top four positions out of 20 , the UK occupies 9 positions out of 20. The positions of leading European university and research centers for publications regarding FT belong to Wageningen in the Netherlands, followed by Rome in Italy.

---insert Table 2 here---

Figure 2 shows the cooperative relationships among the top 20 productive countries in the FT field of research from 1985 to 2015 . Since one of the main purposes of FT is to foster the rights and living conditions of the inhabitants in the developing countries. For this reason, one might expect a great collaboration with institutions and researchers in disadvantaged countries. Conversely, with regard only to the academic world, such involvement of local universities and institutions is missing. Collaborations between countries and institutions concern countries of the so-called Global North, being USA and UK the main cooperative countries. Anyway, it does not mean that FT research has a wick or no relevance to the countries of production, as many studies are based on collaborations with producer cooperatives and local organizations.

---insert Figure 2 here ---

FT appears to be a multidisciplinary research area. This feature can be observed both through the analysis of subject categories and the main sources that published the documents that compose our database. The key disciplines of the data are Business \& Economics (31\%), Agriculture (14\%), Social Sciences (13\%), Public administration (12\%), Environmental sciences (11\%) and Geography (9\%). A total of 432 journals published pertinent literature on FT research all over the world during the 
period between 1985 and 2015. More than 35\% of articles of the database appears in the 16 journals listed in Table 3. Overall, economic journals, especially those with a focus on development and ethical issues related to business, dominate the lists of the most influential journals in the research of FT. However, research on the subject seems to be rather fragmented with regard to the sources, and only the Journal of Business Ethics has a considerable number of publications accounting for almost the $10 \%$ of the dataset.

--- insert Table 3 here ---

\subsection{Article co-citation analysis}

Article co-citation analysis examines the network of co-cited references and is used to map the underlying intellectual structure and dynamics of a field of study (Braam et al., 1991). The results of the top authors and papers in terms of citations are reported in Table 4. Despite the number of citations does not necessarily indicate the quality of a paper, it is a reliable proxy of its impact or visibility. The top five publications with the largest citation nodes are Bacon 2005 (Bacon, 2005), Jaffee 2007 (Jaffee, 2007), De Pelsmacker 2005 (De Pelsmacker et al., 2005), Renard 2003 (Renard, 2003), and Raynolds 2002 (Raynolds, 2002), indicating that these are the most frequently cited articles in FT research.

---insert Table 4 here---

Figure 3 and Table 5 show the network of articles co-citation analysis. For the purposes of co-citation network and bibliographic coupling, only articles that have been cited at least 20 times were used to produce empirical maps of prominent research in the academic discipline. The greater the size of the label, the greater the number of citation within our set of publications, references that are more likely to be cited together are closer each other. Labels are colored according to cluster identity. 
Using a single linkage clustering performed by the software VosViewer, four clusters have been identified, including respectively 33 papers in cluster 1,28 in cluster 2,25 in cluster 3 and 16 in cluster 4.

\author{
---insert Figure 3 here--- \\ ---insert Table 5 here--- \\ ---insert Table 5: (continuation) here---
}

\title{
3.2.1 Cluster 1 - Theoretical foundations of FT
}

Documents in the first cluster theoretically ground the foundations and principles on which FT is built on. Articles of the first cluster provide an overall overview of FT from its origins to its current forms, tracing its history (Raynolds, 2000; Renard, 1999, 2003), explaining its organization (Renard, 2003) and identifying how it developed and grew as a social-quality market niche in a context characterized by agro-food market saturation, concentration of industry and trade, industry's expanding influence in the definition of quality, and homogenization of food practices (Raynolds, 2000; Renard, 1999). Drawing on convention theory (Raynolds, 2002; Renard, 2003) and commodity chain tradition (Raynolds, 2002), the dynamic nature of FT is unveiled showing how FT movement has been always shaped by recurrent tensions, contradictions and compromises on the multiple levels of the network. FT was born as a solidarity and charity model, but later switched to a partnership model (Raynolds, 2002; Tallontire, 2000) by means of a strategy that has been often summarized in the slogan "trade not aid". Later on, FT shifted from alternative trade selling channels - based on direct connections between consumers and producers - to mainstream retailers worldwide, and in more recent time the certification- that was once prerogative of cooperatives - has been extended to some plantation products (Reed, 2009; Renard, 2005).

Several papers of cluster 1 try to define the very nature of FT which contains a basic contradiction (Renard, 2003), summed up in the phrase "in the market but not for it" (Taylor, 2005) or "in and against the market" (Barratt Brown, 1993). 
Documents in the first cluster are for the most part explicitly related to FT, but there are also interesting exceptions as Gereffi (Gereffi Humphrey, j., Sturgeon, T., 2005) and Ponte (Ponte, 2002; Ponte \& Gibbon, 2005), which significantly contributed to the methodology that underpin most studies in the Global commodity chain.

\subsubsection{Cluster 2 - Analysis and Criticism of FT integration in mainstream market}

The second cluster can be interpreted as a further step towards a more detailed analysis of FT in the context of the free market. In particular, the consequences and challenges posed by mainstreaming strategies and shifting power relations within the fair-labeling network are addressed (Hira \& Ferrie, 2006; Low \& Davenport, 2005; Moore, 2004).

The main issues posed by corporations involvement are represented by the risks of marginalization of the original FT mission and principles (Low \& Davenport, 2005; Nicholls \& Opal, 2005), being absorbed by market mindset (Low \& Davenport, 2005; P.L. Taylor et al., 2005), being exploited by big corporations engaged in image-laundering processes (Moore, 2004; Renard, 2003), and by the loss of interest and trust for certifications by consumers, as well as by producers (Nicholls \& Opal, 2005; Raynolds et al., 2007; Reed, 2009).

The papers in this cluster analyze the competition between FT and competitors, which mimic some of the aspects of FT production, and through the use of rival third party certification systems (Moore, 2004; D. Murray \& Raynolds, 2000; Raynolds, 2000; Reed, 2009). Frequently, these competitors are those entities that Raynolds defines "(Those who) hold the bar on social and environmental condition", as they usually have much less rigorous social standards or are not interested in continuous improvement of standards (Raynolds et al., 2007).

The second cluster treats other criticisms concerning the corporation involvement related to governance and power issues within the FT network: (i) the need to create a wider consumer base with increased consumer awareness and better understanding of FT (Hira \& Ferrie, 2006; Moore, 2004; Nicholls \& Opal, 2005), (ii) the shifting power relations within the FT labeling network in 
favor of big companies and retailers (Low \& Davenport, 2005; Raynolds et al., 2004, 2007; Renard, 2005) and (iii) the lack of agreement over definitions of standards and certification procedures (Hira \& Ferrie, 2006).

Barratt Brown (1993) and Nicholls and Opal (2005) recognize the magnitude of the FT in reversing the damages created by the market through instruments offered by the market itself. Barratt Barratt Brown (1993) argues that only through the support and the intervention of international institutions on market regulation these forms of trade will continue to expand, to the point that he proposes the establishment of "a new economic order composed of democratically controlled state marketing boards with grassroots control at all levels, and direct links between Northern consumers and Southern producers" (Fridell, 2007b). On the other hand Nichols and Opal (2005) describe FT as "a consumer-driven phenomenon", "a neoliberal solution to problems with trade", "entirely a consumer choice (based) model", that "operates within the larger free trade model of unregulated international commerce". Emphasis on centrality of consumer demand and consciousness reflects the evolution of the practices of FT, as it shifted from being a proposal of an alternative system to the neoliberal political economy to a form perfectly integrated in the context of the free market (Guthman, 2007; Nicholls \& Opal, 2005).

\subsubsection{Cluster 3 - Consumers}

Documents of the third cluster focus on the consumer side from different points of view, such as marketing, geography, sociology, economy, etc. Studies in this cluster cover a wide range of aspects over FT consumption as it includes both theoretical researches and experimental studies (see Table 5 continuation). Indeed, complexity and diversity of the factors that contribute to the formation of consumers' attitudes and preferences towards FT products makes it necessary to use a wide spectrum of investigation in order to fully understand the mechanisms that underlie consumer choices (Shaw Deirdre; Clarke Ian et al., 2006). 
It is worth noting that the most co-cited documents in the network belong to that branch of studies which uses economic approaches to examine whether or not consumers care about ethical issues, and whether consumers are receptive or not toward ethical certifications. These researches mainly used the willingness to pay (WTP) of consumers as a meter of judgment and offer encouraging results about the effectiveness of ethical labels. The major findings reveal that despite FT advocates are only a minority in the global scenario, the majority of consumers are very receptive toward ethical labels (De Pelsmacker et al., 2005), as they are willing to pay higher premiums, even higher than for organic products or other kinds of certifications like SGC (Shade grown coffee) and organic (Loureiro \& Lotade, 2005).

One of the recurring topics between documents in the third cluster lies is the debate about the limitations of the traditional survey methods in consumer research, and the consequent call for the adoption of methods that can lead to reliable conclusions. As argued by Auger (2007), results from surveys are very likely to overstate the importance of ethical issues and add spurious information into the measurement process. Studies drawing on economic approaches used several methods to get trustworthy empirical insights on FT consumption, as conjoint analysis (De Pelsmacker et al., 2005), contingent analysis (Loureiro \& Lotade, 2005), natural field experiments (Arnot et al., 2006), choice experiment (Auger et al., 2003) and quality approaches (de Ferran \& Grunert, 2007). These considerations are very important in the study of FT consumers and ethical consumption, as they fit into the debate the need for new approaches that can address an issue inherent in a field that is "studying issues with inherent methodological complexities that make understanding human behavior even more difficult than normal" (Auger \& Devinney, 2007).

Past research emphasized the crucial role that information plays in promoting the awareness and sensitivity of consumers to ethical issues, pointing out that in order to unfold accurate decisions, consumers should be fully informed. (Carrigan \& Attala, 2001). (Barnett et al., 2005). (Carrigan \& Attala, 2001). However, it is argued that such theoretical approach could lead to a distorted 
understanding of reality, as it generalizes and trivializes the hierarchies of values that guide consumer decision-making processes and their moral selfhood (Barnett et al., 2005).

Other studies in the cluster inspect different aspects of FT consumers such as sensitivity to price changes for consumers of FT coffee (Arnot et al., 2006) or the role of religion in FT consumption (Doran \& Natale, 2011).

\subsubsection{Cluster 4 - Producers}

The documents of the last cluster focus on the impact of FT on producers and on the evaluation of its effectiveness in improving the well-being of small-scale farmers (see Table 5 continuation).

If the long-term success of FT depends largely on consumer choices (Lyon, 2006), producers' commitment to FT and their understanding of its principles remain two key elements to ensure their participation and commitment in the long term, and to achieve the "democratization of producers' organizations" fostered by FT (D.L. Murray et al., 2006). The risk that producers will turn to FT only in case of very low market prices, and then abandon in more prosperous times, threatens the viability of FT in the long term (Lyon, 2006; D.L. Murray et al., 2006; Nicholls \& Opal, 2005).

Claimed benefits for producers to join FT network are represented by guaranteed minimum price, pre financing and long-term contracts, price premium to be invested in the development and support of the community of producers (Taylor et al., 2005). FT strengthens the organizational capacity of producers, providing greater financial and organizational stability. It bolsters economic security and stability of producers' communities (Raynolds et al., 2004) and infrastructural investment capability, improves livelihood and administrative capacities, increase the level of cooperation and political influence (Arnould et al., 2009; Bacon, 2005; D.L. Murray et al., 2006; Raynolds et al., 2004). Through participation in FT producers acquire skills and knowledge that they can spend also in non-FT markets.

Scientifically demonstrate any positive impact of the FT program on producers and their communities is definitely one of the most challenging aspects of FT research. This ambitious goal is 
made more difficult by the fact that producers sell their products in multiple markets, leading to greater difficulties in identifying the effects of participation in the fair-trade on household income (Bacon, 2005; Bacon et al., 2008; Calo \& Wise, 2005; Valkila, 2009).

Findings from the empirical studies in the network generally converge in supporting the positive impact of FT participation for producers in terms of income (Arnould et al., 2009; Bacon et al., 2008; Raynolds et al., 2004), while assessments in terms of social indicators as education, health (Arnould et al., 2009; Bacon et al., 2008; Becchetti et al., 2006; Raynolds et al., 2004), individual and collective empowerment and capacity building (Raynolds et al., 2004) and environment (Bacon et al., 2008) are slightly more uneven.

In the words of Arnould and Bray, FT "is not a panacea" for third-world poverty (Arnould et al., 2009; Bray et al., 2002), as some producers remain in poverty despite being connected to FT markets, and FT will have to constantly face new challenges to succeed in its mission (Bacon et al., 2008).

\subsection{Article bibliographic coupling analysis}

Bibliographic coupling analysis is based on the assumption that when two papers show similar bibliographies, they are likely to represent the same or at least related research topics. To overcome the "backward looking" of the co-citation analysis we decided to use the bibliographic coupling technique to highlight the Fairtrade recent trends.

The threshold for the minimum shared references between coupled publications was set to 10 .

The bibliographic coupling network (see Figure 4) is composed by three clusters and its structure is quite similar to the one observed in the co-citation network. Many of the most prominent authors of the co-citation network are also represented in the bibliographic coupling network, revealing a high level of specialization and experience of FT researchers. Differently from the cocitation analysis, bibliographic coupling reflects the different changes in FT concept. Scholars 
formalized definitions of FT and set up independent governance and monitoring organizations to oversee FT supply-chain agreements and the licensing of participants (Doherty et al., 2013). Indeed, the rapid expansion experienced by FT in recent decades has introduced new compromises and tensions, and has exacerbated some of the existing ones (Raynolds, 2012).

\section{---insert Figure 4: network of references bibliographic coupling----}

\subsubsection{Cluster 1 - Evolution and challenges of FT}

Despite the relatively heterogeneous body of literature that composes the first cluster, the analysis of the documents reveals that the central debate around the foundational and practical aspects of FT is still inevitably closely linked to the mainstream strategy and its consequences.

The raise of public awareness and the positive relationship between the adoption of the mainstream strategies and expansion of FT market are proposed as clear examples of the success of FT in the last decades (Davies \& Ryals, 2010; Doherty et al., 2013; Raynolds, 2012). However, there is a wide literature inspecting the negative impacts of corporate engagement in the FT network (Child, 2014; Doherty et al., 2013; Jaffee, 2012).

Drawing on previous works on global value chain model, Doherty et al. (2013) assess the degree of risk for dilution, co-optation and reputational damage for the different types of value chains which make up the vast majority of FT purchases today (Doherty et al., 2013). In doing so, they emphasize the need for researchers to consider the heterogeneity of the FT movement, which is composed by many different forms of organization that should not be considered as a single entity.

The growing supply of products with ethical content which resulted in increasing number of ethical brands by firms or retailers (Doherty et al., 2013), as well as the nearly total integration of FT in conventional international markets (Naylor, 2014), render obsolete the narrative of FT being "in and against the market". Naylor (2014) debases this paradigm as an "illusion of an alternative economic imaginary", while Jaffee proposes the recent developments within FT network as an 
example of the risks about the limits of voluntary and non-state regulation, and of the consequences of "growth at any cost" strategy (Jaffee \& Howard, 2010).

It is also argued that consumers have lost that sense of political and collective action that motivated them in the early stages during the 90's and explore new ways to increase the number of FT consumers (Doherty et al., 2013).

Naylor (2014) challenges the dominant theoretical approach that underlies the FT movement and the research on this subject, meaning the dichotomy of "southern producers" Vs "northern consumers", as it perpetuates and reinforces on a semantic level the same disparity in power that FT seeks to equalize. FT research need to re-think approaches that can more fully capture the heterogeneous group of FT actors who have different needs, interests and positions.

\subsubsection{Cluster 2 - Consumption}

Documents of the second cluster of the bibliographic coupling network deal with FT consumption. The research results confirm the need to overcome the dualistic narrative between pragmatic and radical consumers by putting greater attention to consumers heterogeneity and facets (Andorfer \& Liebe, 2012; Cranfield et al., 2010; Kim et al., 2010).

Heterogeneity of consumers is addressed both by comparing samples from various countries or cities (Cranfield et al., 2010; Kim et al., 2010), and widening the spectrum of the products analyzed by investigating product categories different than coffee (Davies et al., 2012; Kim et al., 2010). Previous studies on coffee provide limited focus with little generalizability compared to the wide range of certified products (Kim et al., 2010). To fill this gap, in recent times scholars are exploring areas that have traditionally been poorly investigated by research, such as utilitarian product categories (Kim et al., 2010), luxury goods (Davies et al., 2012) and business-to-business context (Salvador et al., 2014).

People tend to overstate the amount they are willing to pay when asked hypothetical valuation questions compared to when their real money are involved, so that the hypothetical methods can lead 
to values two to twenty times greater than non-hypothetical valuation methods (Lusk \& Shogren, 2007). Therefore, intentions should not be considered a reliable proxy for actual consumer behaviors (Andorfer \& Liebe, 2012; Carrington et al., 2010).

Since we should draw our considerations on what people do, rather than on what they say, what is actually needed is an approach that combines the advantages of revealed and stated preference methods and is able to separate what people say from what they pay, that is using incentive compatible methods that provides incentives for individuals to truthfully reveal their values and imposes a cost for non-truthful (or inaccurate) value revelation (Andorfer \& Liebe, 2012; Carrington et al., 2010; Lusk \& Shogren, 2007).

\subsubsection{Cluster 3 - Producers}

Documents of the third cluster focus on aspects related to the impact of FT certification on producers. Most of the researches rely on experimental case-based studies, reporting very modest or no effects on income, and conflicting results regarding indicators of health, education, and quality of life.

Ruben and Fort (2012) analyze the FT impact for organic and conventional coffee farmers in Peru, and found no significant effect in terms of income. Conversely, Mendez et al. find a significant positive relationship between average sales price, savings, credit, risk acceptance and satisfaction with the cooperative service provision savings (Méndez et al., 2010).

With regard to the non-monetary effects of participation in FT the results are less inconclusive. Participation in FT has been related with better access to credit, higher investment propensity, organic specialization skills, higher levels of animal stocks (Ruben \& Fort, 2012), and increased participation of women in decision making. On the other hand, no connection between FT involvement and positive effects on household livelihood in terms of education and incidence of migration have been found by Mendez et al. (Méndez et al., 2010).

Faced with these conflicting results, it is difficult to assess the efficacy of FT in managing to realize its stated goals. Most marginalized farmers are not able to enter the network and certification 
because of the FT entrance requirements and the lack of support (Omidvar \& Giannakas, 2015; Valkila et al., 2010), while cooperatives are not able to sell their entire production at FT conditions so that certified farmers are often forced to sell consistent portions of their production in the conventional market (Méndez et al., 2010; Valkila et al., 2010).

Some authors point their finger at the price mechanism of FT. FT coffee minimum price hasn't change between 1988 and 2007 (Bacon, 2010; Valkila, 2014): indeed, over the same period, Bacon's findings reveal declining prices when discounted for inflation (Bacon, 2010), fueling allegations related to corporate capture of FT (Jaffee \& Howard, 2010). The decline in the minimum price has shown that the same pricing system is deeply linked to those market prices that it is intended to transform (Bacon, 2010).

The concept of Social premium, despite recent efforts by few authors, remains one of the least studied of FT. There are structural problems in the evaluation of this premium price: it is difficult to separate the benefits derived from premium from those due to other projects for rural development (Valkila \& Nygren, 2010).

\section{Discussion}

Results reveal that the literature on FT has grown exponentially over the past 20 years, during which FT has been studied by different disciplines, which confirms its interdisciplinary nature.

This study went beyond the identification of most productive actors and traditional citation counts, as it uses a bibliometric mapping software tool to visualize the intellectual structure of FT research.

Scientific research of the FT theme mainly developed around four main themes: the philosophical foundations, criticism and challenges posed by the involvement of corporations, consumers, and producer. The same thematic groups can be identified both in the co-citation network, as well as in the bibliographic coupling analysis network of the most recent publications. 
Literature in the early years of research has been strongly influenced by the debates about what should be the role and mission of FT in the scenario of free global market. The recognition of the FT need to cooperate with large corporations in order to continue to pursue its objectives allowed to shift the attention of research to more practical aspects and issues.

Early research focuses mainly on coffee, while in more recent times the spectrum of investigation has been broadened to other certified products, both food and non-food. At the same time the implications of competition from other ethical certification schemes have been investigated in detail. On the side of consumers, this results in the attempt to achieve greater accuracy and generalizability of the results, by using new methodologies to investigate consumer preferences for certified products and WTP and by the attempts to use incentive compatible methods. On the side of producers, research attempts to identify the reasons of the inconclusive results on FT effectiveness and find new ways to assess the effects of the certification on producers.

Findings also suggest that FT as the unique business strategy and/or as a differentiation opportunity for producers, the change in the business attitude to explore FT branding are themes that have been only partially analyzed and deepen.

Like any evolving field of research, it is unsurprising that the documents of the co-citation analysis had a slightly less critical eye over the FT movement than more recent studies. However, despite the critical analysis and resizing of potentialities, authors converge on the need of more consideration of social and economic justice in international trade, and that third-party certification has a key role in ensuring that these goals are addressed. As scholars are confident about the contribution that FT can add to the broader scenario of strategies to enhance living conditions and labor rights for disadvantaged producers and laborers (Méndez et al., 2010), there is also a general agreement on the need for a profound reform of the FT system. FT should address all these issues through a long-term strategy re-organization, involving a participatory representation by smallholder cooperatives, Alternative Trade Organizations and development-oriented civil society movements (Bacon, 2010). 


\section{Conclusion and limitations}

The analysis of literature through bibliographic methods has highlighted the salient aspects of Fairtrade research, from the beginning to the present day, and how the challenges and evolution that FT has been facing over the years have influenced the research and the perspectives of scholars. Compared to the earliest years, when buying FT products was seen as a political statement and the FT network was meant to challenge the neoliberal economic system, FT is now working in close contact with the biggest corporations in the world and certified products can be found on the shelves of supermarkets. During this time, the debate over the engagement of FT by large corporations and the collapse of the model of alternative trade organizations have always remained a central element both within the movement and in scientific research.

Though many years have passed since the participation of corporations in the fairtrade network, the most recent researches do not provide a definitive verdict over the effects of the mainstream strategy. There is no doubt that the implementation of this strategy has been a necessary choice, in terms of expanding the market and the brand, but it is argued that the benefits have not been equally distributed among the actors of the network as many producers still live in conditions of extreme poverty. However, despite the fact that evidence base is still incomplete, there are several evidence of greater income stability and higher earnings for producers who engage the FT network, as well as many other indirect but important benefits.

As for the state of research on FT, two elements emerge: the first one is the low reliability of results on consumers obtained using methods not "incentive compatible" or with low levels of representativeness of the samples. This necessity is not new, Ulrich (Ulrich \& Sarasin, 1995) stated that, with regard to ethical issues, research runs the risk of losing relevance, as the answers are never reliable due to different kinds of biases (Ulrich \& Sarasin, 1995). As stated by Andorfer (Andorfer \& Liebe, 2012), scholars have just begun to understand and explain individual FT consumption, and 
"research on FT consumption would benefit from both a multiple-motives and a multiple-methods perspective". In order to overcome these problems, "incentive-compatible measures of FT consumption intentions and behavior should be used in empirical studies whenever possible" (Andorfer \& Liebe, 2012), comparing different theories and methodologies.

On the side of producers, conflicting and sometimes confusing results concerning the effects of FT, undermined by a number of uncertainties, make it difficult to compare or draw any general conclusions based on the actual evidence base. The question of whether FT producers are better off than their counterparts is very complex and cannot be confined only to questions of price and income differentials. Still, it is possible to draw the conclusions that a comprehensive assessment of the impact of FT should not only account for monetary income, but also for a wide set of welfare, empowerment and quality of life indicator. Furthermore, research should consider also the opinions and perceptions of the participants in the network, as well as their individual skills and performances over time. In addition, limiting the value chain study of coffee and a few cases of a few other certified products, the knowledge on the side of producers is limited in many directions. Discordant results demonstrate the complexity in finding information about the effectiveness of FT and represent an indicator of the limited awareness of the FT system mechanisms and limited identification with FT by producers (Valkila, 2014; Valkila \& Nygren, 2010), two issues on which FT should invest more efforts.

Bibliographical methods are not without limitations. First of all, the tendency of authors to cite their own works can distort the network of citations and give greater emphasis to the most prone authors of this practice. However, the effects of this distortion may be limited when the number of authors is sufficiently high compared to the number of articles published, as in the case of FT literature. Second, high ranked journals tend to be more cited by authors, and this may result in overestimating the contribution of these journals compared to the lower ranking ones. Third, the time between the publication of an article and the moment when that article is cited leads to a greater weight on earlier publications, that - being available for a longer time - received more quotes 
compared to more recent research. Another limitation regards the source from which the data is collected, in this case the Web of Knowledge Core Collection, which is almost entirely composed of articles in English language. Expanding the spectrum of publications even to non-English articles could actually return more complete results. Bibliometric analysis suffers from several limitations that should be considered in the interpretation of the results, the most important of which are introduced below. First of all, there are several reasons for which a document may be cited or not, and a large number of citations does not imply quality. Indeed, bibliometrics does not measure quality and it is important to analyze the documents by combining bibliometric and qualitative methods to evaluate the quality and contributes of works. Then there are some limitations related to the structure and functioning of the world of scientific publishing like the advantage of experienced researchers over early career researchers, and of long running journals over new journals, the different rates of publishing between different fields of research and WOS limited coverage of non-English language publications and books publications.

\section{References}

Andorfer, V.A. and Liebe, U. 2012. Research on Fair Trade Consumption-A Review. Journal of Business Ethics, 106(4): 415-435.

Arnot, C., Boxall, P.C. and Cash, S.B. 2006. Do ethical consumers care about price? A revealed preference analysis of fair trade coffee purchases. Canadian Journal of Agricultural Economics, 54(4): 555-565.

Arnould, E., Plastina, A. and Ball, D. 2009. Does fair trade deliver on its core value proposition? effects on income, educational attainment and health in three countries. American Marketing Association, 28(2): 186-201.

Auger, P., Burke, P., Devinney, T.M. and Louviere, J.J. 2003. What will Consumers Pay for Social Product Features? Journal of Business Ethics, 42(3): 281-304.

Auger, P. and Devinney, T.M. 2007. Do what consumers say matter? The misalignment of preferences with 
unconstrained ethical intentions. Journal of Business Ethics, 76(4): 361-383.

Bacon, C.M. 2005. Confronting the coffee crisis: Can Fair Trade, organic, and specialty coffees reduce small-scale farmer vulnerability in Northern Nicaragua? World Development, 33(3): 497-511.

Bacon, C.M. 2010. Who decides what is fair in fair trade? The agri-environmental governance of standards, access, and price. Journal of Peasant Studies, 37(1): 111-147.

Bacon, C.M., Ernesto Méndez, V., Gómez, M.E.F., Stuart, D. and Flores, S.R.D. 2008. Are Sustainable Coffee Certifications Enough to Secure Farmer Livelihoods? The Millenium Development Goals and Nicaragua's Fair Trade Cooperatives. Globalizations, 5(2): 259-274.

Barnett, C., Cloke, P., Clarke, N. and Malpass, A. 2005. Consuming ethics: Articulating the subjects and spaces of ethical consumption. Antipode, 37(1): 23-45.

Barnett, C., Cloke, P., Clarke, N. and Malpass, A. 2010. Globalizing Responsibility: The Political Rationalities of Ethical Consumption. (C. Barnett, ed.). Oxford: Wiley-Blackwell.

Barratt Brown, M. 1993. Fair Trade: Reform and Realities in the International Trading System. London: Zed Books.

Becchetti, L., Costantino, M. and Vergata, U.T. 2006. Working Paper Series The effects of Fair Trade on marginalised producers : an impact analysis on Kenyan farmers. Economia,.

Braam, R., Moed, H. and Vanraaf, A. 1991. Mapping of Sciencce by Combined Cocitation and Word Analysis.1. Structural Aspects. Journal of the American Society for Information Science, 42(4): 233251.

Bray, D.B., Sanchez, J.L.P. and Murphy, E.C. 2002. Social dimensions of organic coffee production in Mexico: lessons for eco-labeling initiatives. Society and Natural Resources, 15: 429-444.

Cadbury.co.uk. 2016. 2009 Cadbury dairy milk becomes Fairtrade. Retrieved from https://www.cadbury.co.uk/the-story/cadbury-dairy-milk-becomes-fairtrade

Calo, M. and Wise, T. a. 2005. Revaluing Peasant Coffee Production : Organic and Fair Trade Markets in 
Mexico. Global Development and Environment Institute, (October): 1-57.

Carrefour. 2014. 2014 annual activity and responsible commitment report. Retrieved from http://www.carrefour.com/sites/default/files/RA_2014_EN.pdf

Carrigan, M. and Attala, A. 2001. The myth of the ethical consumer - do ethics matter in purchase behaviour? Journal of Consumer Marketing, 18.

Carrington, M.J., Neville, B.A. and Whitwell, G.J. 2010. Why ethical consumers don't walk their talk: Towards a framework for understanding the gap between the ethical purchase intentions and actual buying behaviour of ethically minded consumers. Journal of Business Ethics, 97(1): 139-158.

Child, C. 2014. Mainstreaming and its Discontents: Fair Trade, Socially Responsible Investing, and Industry Trajectories. Journal of Business Ethics, 130(3): 601-618.

Cobo, M.J., López-Herrera, A.G., Herrera-Viedma, E. and Herrera, F. 2011. An approach for detecting, quantifying, and visualizing the evolution of a research field: A practical application to the Fuzzy Sets Theory field. Journal of Informetrics, 5(1): 146-166.

Cranfield, J., Henson, S., Northey, J. and Masakure, O. 2010. An assessment of consumer preference for fair trade coffee in Toronto and Vancouver. Agribusiness, 26(2): 307-325.

Davies, I.A., Doherty, B. and Knox, S. 2010. The rise and stall of a fair trade pioneer: The cafè direct story. Journal of Business Ethics, 92(1): 127-147.

Davies, I.A., Lee, Z. and Ahonkhai, I. 2012. Do Consumers Care About Ethical-Luxury? Journal of Business Ethics, 106(1): 37-51.

Davies, I.A. and Ryals, L.J. 2010. The Role of Social Capital in the Success of Fair Trade. Journal of Business Ethics, 96(2): 317-338.

de Ferran, F. and Grunert, K.G. 2007. French fair trade coffee buyers' purchasing motives: An exploratory study using means-end chains analysis. Food Quality and Preference, 18(2): 218-229.

De Pelsmacker, P., Driesen, L. and Rayp, G. 2005. Do Consumers Care about Ethics? Willingness to Pay for 
Fair-Trade Coffee. Journal of Consumer Affairs, 39(2): 363-385.

De Solla Price, D.J. 1965. Networks of Scientific Papers. Science, 149(3683): 510-515.

Doherty, B., Davies, I. a. and Tranchell, S. 2013. Where now for fair trade? Business History, 55(2): 161189.

Doherty, B., Smith, A. and Parker, S. 2015. Fair Trade market creation and marketing in the Global South. Geoforum, 67: 158-171.

Doran, C.J. and Natale, S.M. 2011. Empatheia and Caritas: The Role of Religion in Fair Trade Consumption. Journal of Business Ethics, 98(1): 1-15.

Eck, N.J. Van and Waltman, L. 2014. Visualizing bibliometric networks. In W. D. Ding Y., Rousseau R. (ed.), Measuring scholarly impact: Methods and practice.

Fair Trade Advocacy Office. 2013. Vote for FT campaign. Retrieved from http://www.fairtradeadvocacy.org/about-the-campaign

Fairtrade Foundation. 2016. Starbucks. Retrieved from http://www.fairtrade.org.uk/en/buyingfairtrade/coffee/starbucks

Fairtrade International. 2012. Annual report 2010-11. Bonn, Germany. Retrieved from https://www.fairtrade.net/fileadmin/user_upload/content/2009/about_us/documents/FLO_AnnualReview_2010-2011_complete_lowres_single.pdf

Fairtrade International. 2014. Annual report 2012-13. Bonn, Germany. Retrieved from https://www.fairtrade.net/fileadmin/user_upload/content/2009/resources/201213_AnnualReport_FairtradeIntl_web.pdf

Fairtrade International. 2015. Annual Report 2013-14. Bonn, Germany. Retrieved from https://www.fairtrade.net/fileadmin/user_upload/content/2009/resources/201314_AnnualReport_FairtradeIntl_web.pdf

Fairtrade International. 2016a. Annual report 2015-2016. Retrieved from https://annualreport15- 
16.fairtrade.net/en/

Fairtrade International. 2016b. Boost for Cocoa and Sugar Farmers as Ferrero Increases its Fairtrade Commitment. Retrieved 8 June 2016, from https://www.fairtrade.net/new/latest-news/singleview/article/boost-for-cocoa-and-sugar-farmers-as-ferrero-increases-its-fairtrade-commitment.html

Fairtrade Labelling Organizations International. 2016. Fairtrade minimum price and fairtrade premium table. Retrieved 20 October 2016, from https://www.fairtrade.net/fileadmin/user_upload/content/2009/standards/documents/2016-1020_EN_Fairtrade_Minimum_Price_and_Premium_table.pdf

Fairtrade UK. 2016. About Coffee. Retrieved from http://www.fairtrade.org.uk/en/farmers-andworkers/coffee/about-coffee

Fetscherin, M. and Heinrich, D. 2015. Consumer brand relationships research: A bibliometric citation metaanalysis. Journal of Business Research, 68(2): 380-390.

Fridell, G. 2007a. Fair-Trade Coffee and Commodity Fetishism: the limits of market-driven social justice. Historical Materialism, 15(4): 79-104.

Fridell, G. 2007b. Fair Trade Coffee: The Prospects and Pitfalls of Market-Driven Social Justice. University of Toronto Press.

Garfield, E. 1955. Citation Indexes for Science: A New Dimension in Documentation through Association of Ideas. Science, 122(3159): 108-111.

Garfield, E. and Sher, I.H. 1993. KeyWords PlusTM - Algorithmic Derivative Indexing. Journal of the American Society for Information Science, 44(5): 298.

Gereffi, G. 1994. The Organization of Buyer-Driven Global Commodity Chains: HowU.S. Retailers Shape Overseas Production Networks. In G. Gereffi \& M. Korzeniewicz (eds.), Commodity Chains and Global Capitalism, Westport: Praeger.

Gereffi Humphrey, j., Sturgeon, T., G. 2005. The governance of global value chains. Review of International 
Political Economy, 12(1): 78-104.

Glänzel, W. and Czerwon, H.J. 1996. A new methodological approach to bibliographic coupling and its application to the national, regional and institutional level. Scientometrics, 37(2): 195-221.

Goodman, M.K. 2004. Reading fair trade: Political ecological imaginary and the moral economy of fair trade foods. Political Geography, 23(7 SPEC.ISS.): 891-915.

Grankvist, G. 2012. Consumer attitudes to ethically labelled products. Retrieved from http://primo.plymouth.ac.uk/primo_library/libweb/action/display.do?tabs=viewOnlineTab\&ct=display $\& \mathrm{fn}=$ search $\& \mathrm{doc}=\mathrm{TN} \_$swepubhv-5126\&indx $=2 \&$ recIds $=$ TN_swepubhv5126\&recIdxs=1\&elementId=\&renderMode=poppedOut\&displayMode=full\&http://primo.plymouth.ac .uk:80/primo

Guthman, J. 2007. The polanyian way? Voluntary food labels as neoliberal governance. Antipode, 39(3): $456-478$.

Hira, A. and Ferrie, J. 2006. Fair trade: Three key challenges for reaching the mainstream. Journal of Business Ethics, 63(2): 107-118.

Hudson, I. and Hudson, M. 2003. Removing the Veil?: Commodity Fetishism, Fair Trade, and the Environment. Organization \& Environment, 16(4): 413-430.

Jaffee, D. 2007. Brewing Justice Fair Trade Coffee, Sustainability, and Survival. United States of America: University of California Press.

Jaffee, D. 2012. Weak Coffee: Certification and Co-Optation in the Fair Trade Movement. Social Problems, 59(1): 94-116.

Jaffee, D. and Howard, P.H. 2010. Corporate cooptation of organic and fair trade standards. Agriculture and Human Values, 27(4): 387-399.

Jarneving, B. 2007. Bibliographic coupling and its application to research-front and other core documents. Journal of Informetrics, 1(4): 287-307. 
Kim, G.S., Lee, G.Y. and Park, K. 2010. A Cross-National Investigation on How Ethical Consumers Build Loyalty Toward Fair Trade Brands. Journal of Business Ethics, 96(4): 589-611.

Lines, T. 2005. Agricultural Commodities, Trade and Sustainable Development. (I.I. for E. and D. (IIED) and International \& C. for T. and S.D. (ICTSD), eds.). London.

López-Fernández, M.C., Serrano-Bedia, A.M. and Pérez-Pérez, M. 2016. Entrepreneurship and Family Firm Research: A Bibliometric Analysis of An Emerging Field. Journal of Small Business Management, 54(2): 622-639.

Loureiro, M.L. and Lotade, J. 2005. Do fair trade and eco-labels in coffee wake up the consumer conscience? Ecological Economics, 53(1): 129-138.

Low, W. and Davenport, E. 2005. Postcards from the edge: maintaining the 'alternative'character of fair trade. Sustainable Development, 13(3): 143-153.

Lusk, J.L. and Shogren, J.F. 2007. Experimental Auctions. Cambridge Journal of Economics,. Retrieved from http://ebooks.cambridge.org/ref/id/CBO9780511611261

Lyon, S. 2006. Evaluating fair trade consumption: politics, defetishization and producer participation. International Journal of Consumer Studies, 30(5): 452-464.

Mars Incorporated. 2016. Mars cocoa policy. Retrieved from http://www.mars.com/global/about-us/policiesand-practices/cocoa-policy

Marshakova, I. 1973. System of Document Connections Based on References. Nauchn-Techn.Inform., 2(6): $3-8$.

Marston, A. 2013. Justice for all? Material and semiotic impacts of Fair Trade craft certification. Geoforum, 44: $162-169$.

Méndez, V.E., Bacon, C.M., Olson, M., Petchers, S., Herrador, D., Carranza, C., ... Mendoza, A. 2010. Effects of Fair Trade and organic certifications on small-scale coffee farmer households in Central America and Mexico. Renewable Agriculture and Food Systems, 25(3): 236-251. 
Micheletti, M. 2003. Political Virtue and Shopping - Individuals, Consumerism, and Collective Action. Palgrave Macmillan US.

Micheletti, M. and Stolle, D. 2005. The Concept of Political Consumerism. In Youth Activism-An International Encyclopedia.

Moed, H.F., Glänzel, W. and Schmoch, U. 2005. Handbook of Quantitative Science and Technology Research. Netherlands: Springer Netherlands.

Moore, G. 2004. The fair trade Movement: Parameters, Issues and Future Research. Journal of business ethics, 53(1-2): 73-86.

Moore, G. 2015. The Fair Trade Movement : Issues and Future Research 53(1): 73-86.

Murray, D. and Raynolds, L. 2000. Alternative trade in bananas: Obstacles and opportunities for progressive social change in the global economy. Agriculture and Human values, 65-74.

Murray, D.L., Raynolds, L.T. and Taylor, P.L. 2006. The future of Fair Trade coffee: dilemmas facing Latin America's small-scale producers. Development in Practice, 16(2): 179-192.

Naylor, L. 2014. 'Some are more fair than others': Fair trade certification, development, and North-South subjects. Agriculture and Human Values, 31(2): 273-284.

Nestlé. 2016. Nestlè cocoa plan. Retrieved from http://www.nestlecocoaplan.com/

Nicholls, A. and Opal, C. 2005. Fair Trade Market-Driven Ethical Consumption. London: SAGE Publications Ltd.

Noyons, E.C.M., Moed, H.F. and Luwel, M. 1999. Combining mapping and citation analysis for evaluative bibliometric purposes: A bibliometric study. Journal of the American Society for Information Science, 50(2): 115-131.

Omidvar, V. and Giannakas, K. 2015. The effects of fair trade on coffee growers: A framework and analysis. Agricultural Economics (United Kingdom), 46: 29-39. 
Ponte, S. 2002. The 'Latte Revolution'? Regulation, markets and consumption in the global coffee chain. World Development, 30(7): 1099-1122.

Ponte, S. and Gibbon, P. 2005. Quality standards, conventions and the governance of global value chains. Economy and Society, 34(1): 1-31.

Porter, M. 1990. Competitive Advantage of Nations. Competitive Intelligence Review, 1(1): 14-14.

Raynolds, L.T. 2000. Re-embedding global agriculture: The international organic and fair trade movements. Agriculture and Human Values, 17(3): 297-309.

Raynolds, L.T. 2002. Consumer/producer links in fair trade coffee networks. Sociologia Ruralis, 42(4): 404424.

Raynolds, L.T. 2012. Fair Trade: Social regulation in global food markets. Journal of Rural Studies, 28(3): $276-287$.

Raynolds, L.T. 2014. Fairtrade, certification, and labor: Global and local tensions in improving conditions for agricultural workers. Agriculture and Human Values, 31(3): 499-511.

Raynolds, L.T., Murray, D. and Heller, A. 2007. Regulating sustainability in the coffee sector: A comparative analysis of third-party environmental and social certification initiatives. Agriculture and Human Values, 24(2): 147-163.

Raynolds, L.T., Murray, D. and Taylor, P.L. 2004. Fair Trade coffee: Building producer capacity via global networks. Journal of International Development, 16(8): 1109-1121.

Raynolds, L.T. and Ngcwangu, S.U. 2010. Fair Trade Rooibos tea: Connecting South African producers and American consumer markets. Geoforum, 41(1): 74-83.

Reed, D. 2009. What do corporations have to do with fair trade? positive and normative analysis from a value chain perspective. Journal of Business Ethics, 86(SUPPL. 1): 3-26.

Renard, M.C. 1999. The Interstices of Globalization: The Example of Fair Coffee. Sociologia Ruralis, 39(4): 484-500. 
Renard, M.C. 2003. Fair trade: Quality, market and conventions. Journal of Rural Studies, 19(1): 87-96.

Renard, M.C. 2005. Quality certification, regulation and power in fair trade. Journal of Rural Studies, 21(4): 419-431.

Ruben, R. and Fort, R. 2012. The Impact of Fair Trade Certification for Coffee Farmers in Peru. World Development, 40(3): 570-582.

Salvador, R.O., Merchant, A. and Alexander, E.A. 2014. Faith and Fair Trade: The Moderating Role of Contextual Religious Salience. Journal of Business Ethics, 121(3): 353-371.

Sharabchiev, J.T. 1988. Comparative analysis of two methods of cluster analysis of bibliographic. NauchnoTekhnicheskaya Informatsiya, 2(4): 25-28.

Shaw Deirdre; Clarke Ian, Shaw, D., Clarke, I. and Shaw, D. 2006. Belief formation in ethical consumer groups : an exploratory study Belief formation in ethical consumer groups : an exploratory study. Marketing Intelligence \& Planning, 17(2): 109-120.

Shreck, A. 2005. Resistance, redistribution, and power in the Fair Trade banana initiative. Agriculture and Human Values, 22(1): 17-29.

Small, H.G. 1973. Co-citation in the Scientific Literature: A New Measure of the Relationship Between Two Documents. Journal of the American Society for Information Science, 24(4): 265-269.

Small, H.G. 1980. Co-citation context analysis and the structure of paradigms. Journal of Documentation, 36(3): 183-196.

Small, H.G. 1997. Update on science mapping: Creating large document spaces. Scientometrics, 38(2): 275293.

Small, H.G. 2006. Tracking and predicting growth areas in science. SCIENTOMETRICS, 68(3): 595-610.

Small, H.G. and Crane, D. 1979. Specialties and disciplines in science and social science: An examination of their structure using citation indexes. Scientometrics, 1(5): 445-461. 
Small, H.G. and Griffith, B.C. 1974. The structure of scientific literature: Identifying and graphing specialties. Science Studies, 4(1): 17-40.

Tallontire, A. 2000. Partnerships in Fair Trade : Reflections from a Case Study of Cafédirect (Partenariats dans Partnerships in fair trade : reflections from a case study of Cafedirect). Development in Practice, 10(2): 166-177.

Tate \& Lyle Sugar. 2016. Our Fairtrade Promise. Retrieved from https://www.tateandlylesugars.com/us/weare-fairtrade

Taylor, J.E. and Boasson, V. 2014. Who buys fair trade and why (or Why Not)? A random survey of households. Journal of Consumer Affairs, 48(2): 418-430.

Taylor, P.L. 2005. In the market but not of it: Fair trade coffee and forest stewardship council certification as market-based social change. World Development, 33(1): 129-147.

Taylor, P.L., Murray, D.L. and Raynolds, L.T. 2005. Keeping trade fair: Governance challenges in the fair trade coffee initiative. Sustainable Development, 13(3): 199-208.

Tesco PLC. 2016. Tesco Fairtrade policy.

Ulrich, P. and Sarasin, C. 1995. Facing Public Interest: The Ethical Challenge to Business Policy and Corporate Communications. Springer Netherlands.

Valkila, J. 2009. Fair Trade organic coffee production in Nicaragua - Sustainable development or a poverty trap? Ecological Economics, 68(12): 3018-3025.

Valkila, J. 2014. Do Fair Trade Pricing Policies Reduce Inequalities in Coffee Production and Trade ? 32(4): 475-493.

Valkila, J., Haaparanta, P. and Niemi, N. 2010. Empowering Coffee Traders? The Coffee Value Chain from Nicaraguan Fair Trade Farmers to Finnish Consumers. Journal of Business Ethics, 97(2): 257-270.

Valkila, J. and Nygren, A. 2010. Impacts of Fair Trade certification on coffee farmers, cooperatives, and laborers in Nicaragua. Agriculture and Human Values, 27(3): 321-333. 
VanEck, N.J. and Waltman, L. 2010. Software survey: VOSviewer, a computer program for bibliometric mapping. Scientometrics, 84(2): 523-538.

VanEck, N.J. and Waltman, L. 2014. Measuring Scholarly Impact. Measuring Scholarly Impact: Methods and Practice, (1982): 285-320.

VanEck, N.J., Waltman, L., Dekker, R. and van den Berg, J. 2013. Measuring use and creation of open educational resources in higher education. International Review of Research in Open and Distance Learning, 14(4): 90-103.

Vladutz, G. and Cook, J. 1984. Bibliographic coupling and subject relatedness. Proceedings of the American Society for Information Science, 21: 204-207.

Waltman, L., van Eck, N.J. and Noyons, E.C.M. 2010. A unified approach to mapping and clustering of bibliometric networks. Journal of Informetrics, 4(4): 629-635.

Whatmore, S. and Thorne, L. 1997. Nourishing Networks: Alternative Geographies of Food. In Globalising Food: Agrarian Questions and Global Restructuring,. Goodman, D.; Watts, M.

World Fair Trade Organization, Fairtrade International and FLO-CERT. 2011. Fair Trade Glossary. Retrieved 28 June 2011, from https://www.fairtrade.net/fileadmin/user_upload/content/2009/about_fairtrade/2011-06-28_fair-tradeglossary_WFTO-FLO-FLOCERT.pdf 
Figure 1: The growth trends of FT publications, authors and citations.

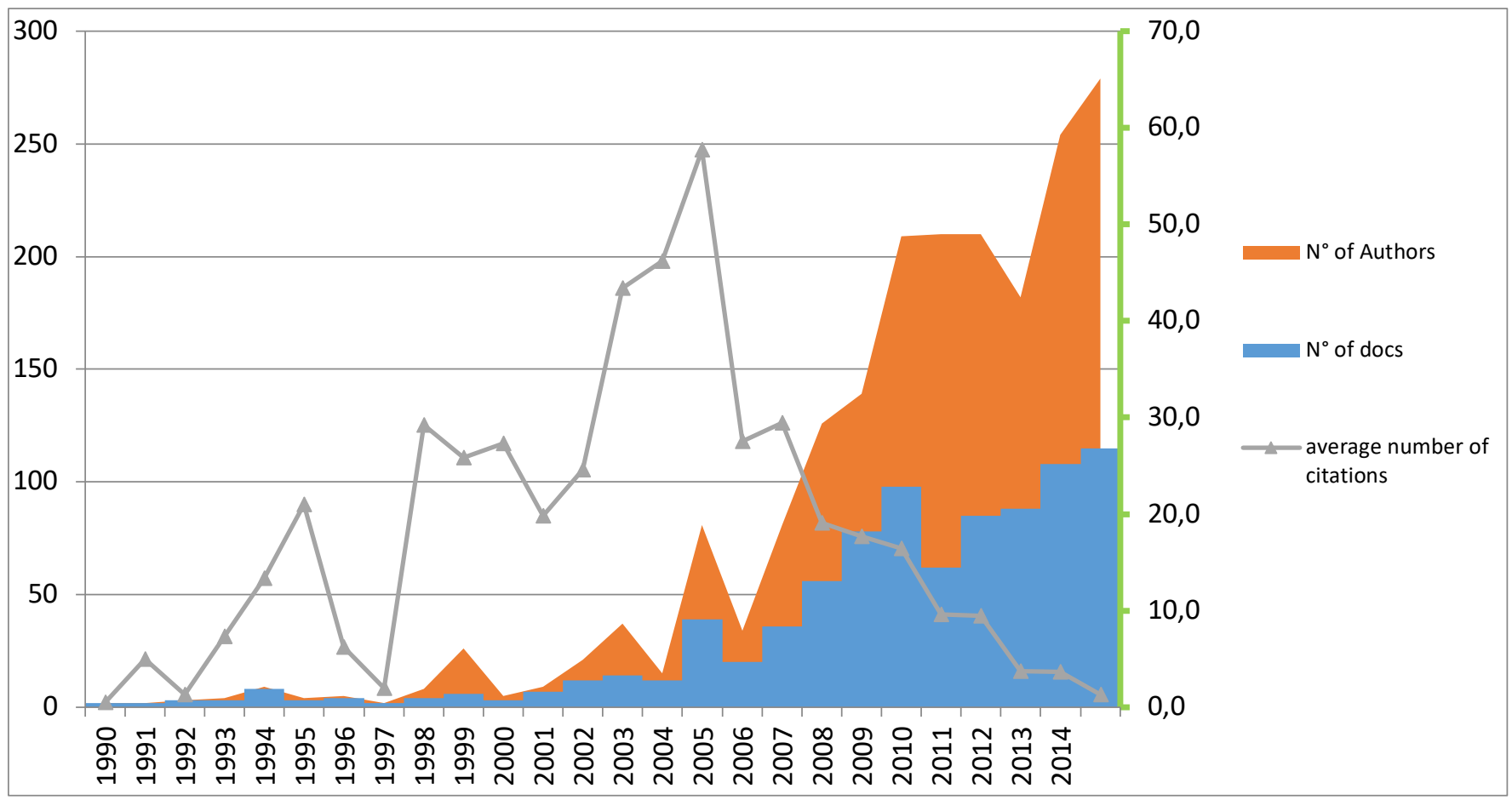

Figure 2: Network of collaborations between countries

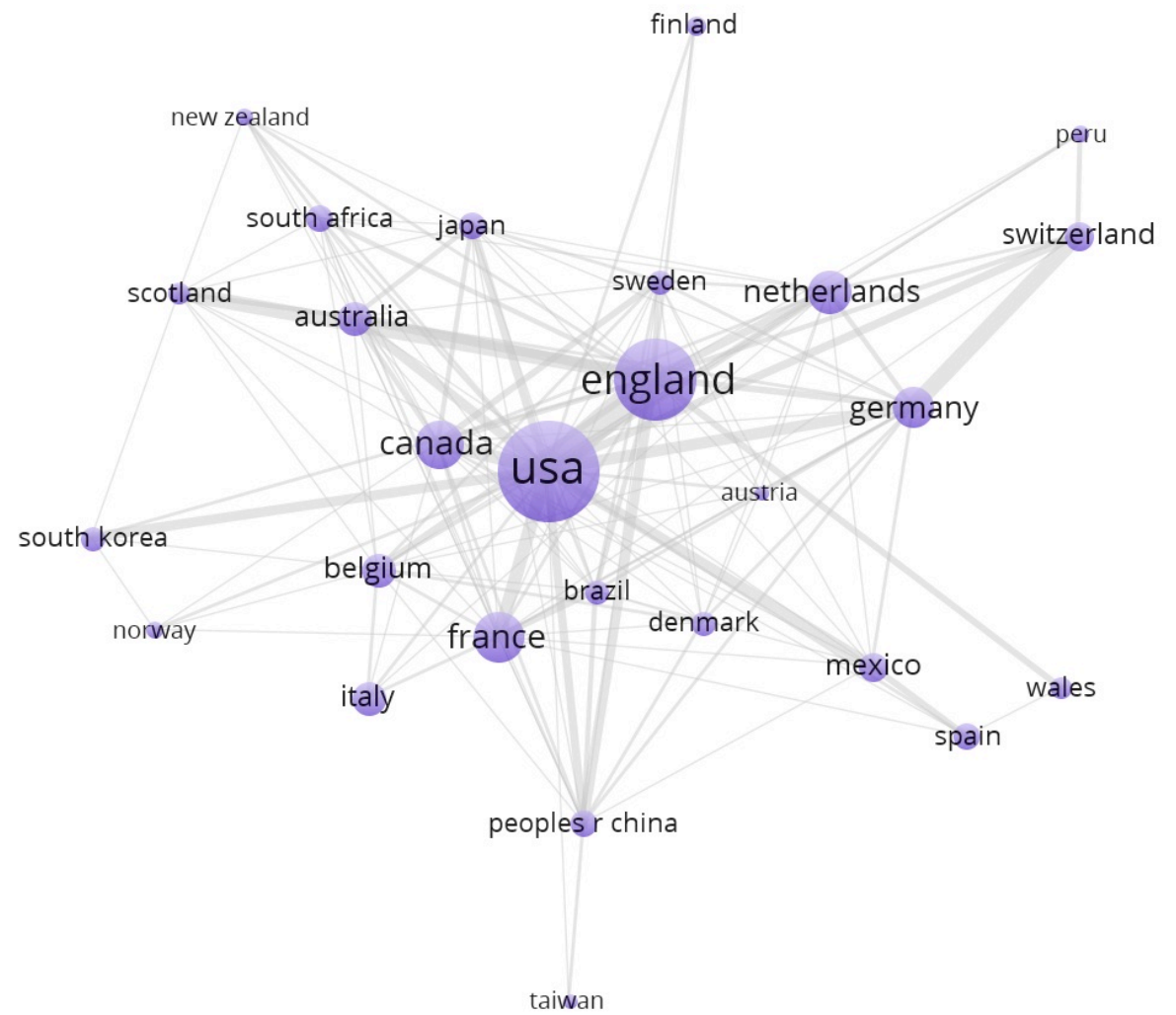


Figure 3: Network of references co-citation analysis

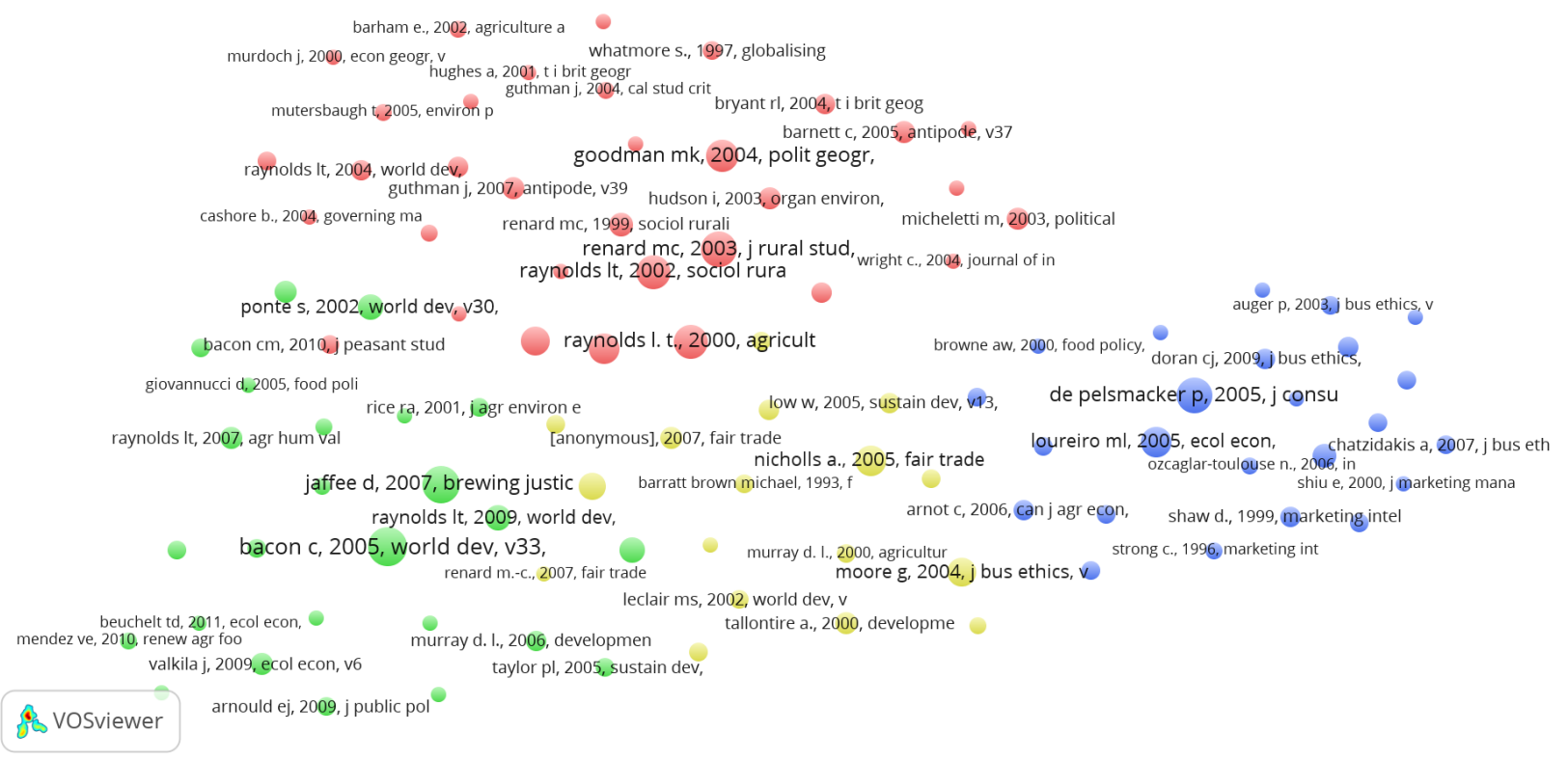

Figure 4: Network of references bibliographic coupling

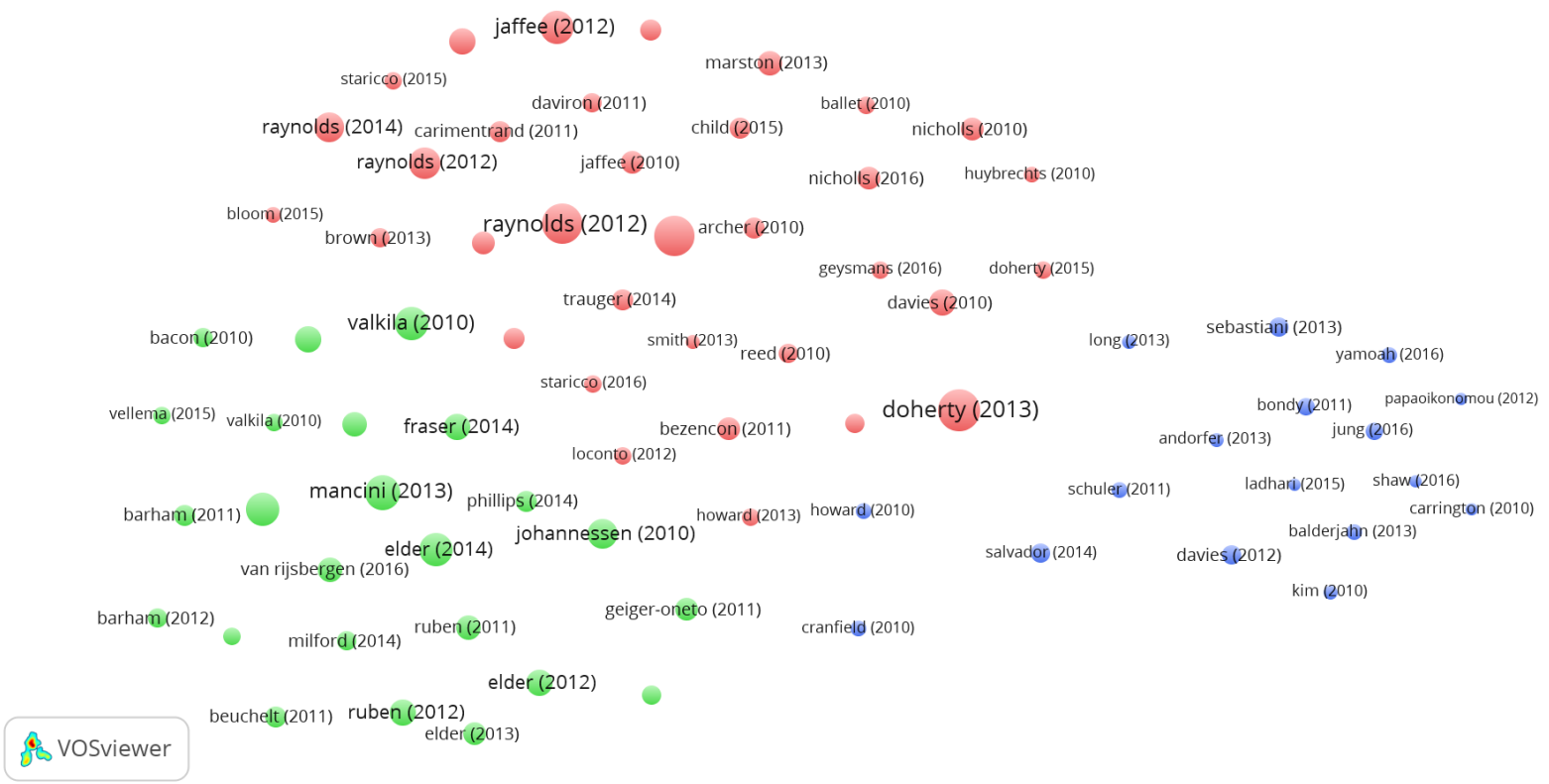


Table1: quantitative analysis of trends of research on FT

\begin{tabular}{|c|c|c|c|c|c|c|c|c|}
\hline Year & $\begin{array}{c}\text { total } \\
\text { publications }\end{array}$ & $\begin{array}{c}\mathbf{N}^{\circ} \text { of } \\
\text { Authors }\end{array}$ & $\begin{array}{c}\mathbf{N}^{\circ} \mathrm{Au} / \mathrm{N}^{\circ} \\
\text { Docs }\end{array}$ & $\begin{array}{l}\text { Times } \\
\text { Cited }\end{array}$ & $\begin{array}{c}\text { average } \\
\text { number } \\
\text { of } \\
\text { citations }\end{array}$ & $\begin{array}{c}\text { No of } \\
\text { references }\end{array}$ & $\begin{array}{l}\text { NR/N } N^{\circ} \text { of } \\
\text { docs }\end{array}$ & $\begin{array}{l}\text { years of cited } \\
\text { references in } \\
\text { the dataset }\end{array}$ \\
\hline 1990 & 2 & 2 & 1,0 & 1 & 0,5 & 12 & 6,0 & 410 \\
\hline 1991 & 2 & 2 & 1,0 & 10 & 5,0 & 39 & 19,5 & 562 \\
\hline 1992 & 3 & 3 & 1,0 & 4 & 1,3 & 29 & 9,7 & 524 \\
\hline 1993 & 3 & 4 & 1,3 & 22 & 7,3 & 302 & 100,7 & 631 \\
\hline 1994 & 8 & 9 & 1,1 & 107 & 13,4 & 170 & 21,3 & 727 \\
\hline 1995 & 3 & 4 & 1,3 & 63 & 21,0 & 69 & 23,0 & 780 \\
\hline 1996 & 4 & 5 & 1,3 & 25 & 6,3 & 61 & 15,3 & 906 \\
\hline 1997 & 2 & 2 & 1,0 & 4 & 2,0 & 0 & 0,0 & 1123 \\
\hline 1998 & 4 & 8 & 2,0 & 117 & 29,3 & 124 & 31,0 & 1102 \\
\hline 1999 & 6 & 26 & 4,3 & 155 & 25,8 & 183 & 30,5 & 1383 \\
\hline 2000 & 3 & 5 & 1,7 & 82 & 27,3 & 57 & 19,0 & 2103 \\
\hline 2001 & 7 & 9 & 1,3 & 139 & 19,9 & 140 & 20,0 & 1980 \\
\hline 2002 & 12 & 21 & 1,8 & 295 & 24,6 & 303 & 25,3 & 2742 \\
\hline 2003 & 14 & 37 & 2,6 & 608 & 43,4 & 374 & 26,7 & 2807 \\
\hline 2004 & 12 & 15 & 1,3 & 554 & 46,2 & 555 & 46,3 & 2927 \\
\hline 2005 & 39 & 81 & 2,1 & 2250 & 57,7 & 1854 & 47,5 & 3817 \\
\hline 2006 & 20 & 34 & 1,7 & 550 & 27,5 & 1043 & 52,2 & 2980 \\
\hline 2007 & 36 & 81 & 2,3 & 1061 & 29,5 & 1799 & 50,0 & 3515 \\
\hline 2008 & 56 & 126 & 2,3 & 1068 & 19,1 & 2308 & 41,2 & 3066 \\
\hline 2009 & 78 & 139 & 1,8 & 1383 & 17,7 & 3816 & 48,9 & 2939 \\
\hline 2010 & 98 & 209 & 2,1 & 1613 & 16,5 & 5319 & 54,3 & 2714 \\
\hline 2011 & 62 & 210 & 3,4 & 596 & 9,6 & 3179 & 51,3 & 2012 \\
\hline 2012 & 85 & 210 & 2,5 & 806 & 9,5 & 5077 & 59,7 & 1612 \\
\hline 2013 & 88 & 182 & 2,1 & 327 & 3,7 & 4855 & 55,2 & 1066 \\
\hline 2014 & 108 & 254 & 2,4 & 397 & 3,7 & 6215 & 57,5 & 726 \\
\hline 2015 & 115 & 279 & 2,4 & 148 & 1,3 & 6986 & 60,7 & 259 \\
\hline
\end{tabular}


Table 2: Top 15 most productive countries and institutes in FT research.

\begin{tabular}{|l|c|c|l|c|}
\hline \multicolumn{1}{|c|}{ Country } & $\mathbf{N}$ & $\mathbf{\%}$ & \multicolumn{1}{|c|}{ Most productive institutes } & $\mathbf{N}$ \\
\hline USA & 281 & $26 \%$ & Colorado State Univ (USA) & 18 \\
\hline UK & 198 & $19 \%$ & Univ Calif Santa Cruz (USA) & 16 \\
\hline France & 71 & $8 \%$ & Michigan State Univ (USA) & 16 \\
\hline Canada & 66 & $6 \%$ & Wageningen Univ (NETHERLANDS) & 15 \\
\hline Netherlands & 53 & $4 \%$ & Univ Warwick (UK) & 14 \\
\hline Germany & 50 & $4 \%$ & Univ Wisconsin (USA) & 14 \\
\hline Australia & 35 & $4 \%$ & Univ British Columbia (USA) & 12 \\
\hline Italy & 34 & $3 \%$ & Univ Oxford (UK) & 12 \\
\hline Belgium & 31 & $2 \%$ & Univ Roma Tor Vergata (ITALY) & 11 \\
\hline Mexico & 25 & $2 \%$ & Univ Lancaster (UK) & 11 \\
\hline Switzerland & 25 & $2 \%$ & Univ Kentucky (USA) & 11 \\
\hline China & 21 & $2 \%$ & Univ London (UK) & 10 \\
\hline Japan & 21 & $2 \%$ & Univ Sheffield (UK) & 10 \\
\hline Spain & 21 & $2 \%$ & York Univ (UK) & 9 \\
\hline South Africa & 20 & $1 \%$ & Vrije Univ Amsterdam (NETHERLANDS) \\
\hline
\end{tabular}

Table 3: ranking of the most productive journals and most common subject categories

\begin{tabular}{|c|c|c|c|c|c|}
\hline Journal & $N^{\circ}$ of docs & $\%$ & Subject Categories & $\mathrm{N}^{\circ}$ of docs & $\%$ \\
\hline Journal of business ethics & 83 & $9 \%$ & Business \& Economics & 340 & $22 \%$ \\
\hline Geoforum & 31 & $3 \%$ & Social Sciences - Other Topics & 147 & $9 \%$ \\
\hline International journal of consumer studies & 26 & $3 \%$ & Agriculture & 129 & $8 \%$ \\
\hline Agriculture and human values & 24 & $2 \%$ & Public Administration & 121 & $8 \%$ \\
\hline Journal of rural studies & 17 & $2 \%$ & Environmental Sciences \& Ecology & 109 & $7 \%$ \\
\hline World development & 17 & $2 \%$ & Geography & 90 & $6 \%$ \\
\hline Sustainable development & 17 & $2 \%$ & Sociology & 78 & $5 \%$ \\
\hline Third world quarterly & 13 & $1 \%$ & Government \& Law & 69 & $4 \%$ \\
\hline British food journal & 13 & $1 \%$ & Food Science \& Technology & 52 & $3 \%$ \\
\hline Environment and planning a & 12 & $1 \%$ & International Relations & 47 & $3 \%$ \\
\hline Journal of international development & 11 & $1 \%$ & Science \& Technology - Other Topics & 44 & $3 \%$ \\
\hline Journal of cleaner production & 10 & $1 \%$ & History \& Philosophy of Science & 35 & $2 \%$ \\
\hline Globalizations & 10 & $1 \%$ & Nutrition \& Dietetics & 24 & $2 \%$ \\
\hline Cahiers agricultures & 10 & $1 \%$ & Engineering & 24 & $2 \%$ \\
\hline Ecological economics & 10 & $1 \%$ & Anthropology & 21 & $1 \%$ \\
\hline Food quality and preference & 10 & $1 \%$ & & & \\
\hline
\end{tabular}


Table 4: Ranking of the most cited authors and publications. TC = Total number of citations, not available

for books. IC= number of citations by the documents of the database.

\begin{tabular}{|c|c|c|c|c|c|c|}
\hline$A U$ & TC & IC & Pubblication & Title & IC & TC \\
\hline Raynolds L & 342 & 561 & Bacon C, 2005, V33, P497, World Dev & $\begin{array}{l}\text { Confronting the coffee crisis: Can Fair Trade, } \\
\text { organic, and specialty coffees reduce small-scale } \\
\text { farmer vulnerability in northern Nicaragua? }\end{array}$ & 116 & 224 \\
\hline Renard M & 102 & 283 & Jaffee D, 2007 & $\begin{array}{l}\text { Brewing Justice Fair Trade Coffee, Sustainability, } \\
\text { and Survival }\end{array}$ & 106 & - \\
\hline Bacon C & 312 & 244 & $\begin{array}{l}\text { Renard M, 2003, V19, P87, J Rural } \\
\text { Stud }\end{array}$ & Fair trade: quality, market and conventions & 97 & 179 \\
\hline Jaffee D & 46 & 209 & $\begin{array}{l}\text { De Pelsmacker P, 2005, V39, P363, J } \\
\text { Consum Aff }\end{array}$ & $\begin{array}{l}\text { Do Consumers Care about Ethics? Willingness to } \\
\text { Pay for Fair-Trade Coffee }\end{array}$ & 97 & 237 \\
\hline DePelsmacker P & 126 & 176 & $\begin{array}{l}\text { Raynolds L, 2002, V42, P404, Sociol } \\
\text { Ruralis }\end{array}$ & $\begin{array}{l}\text { Consumer/Producer Links in Fair Trade Coffee } \\
\text { Networks }\end{array}$ & 88 & 171 \\
\hline Guthman J & 37 & 170 & $\begin{array}{l}\text { Raynolds L, 2000, V17, P297, } \\
\text { Agriculture And Human Values }\end{array}$ & $\begin{array}{l}\text { Re-embedding global agriculture: The } \\
\text { international organic and fair trade movements }\end{array}$ & 86 & 207 \\
\hline Ponte S & 52 & 157 & $\begin{array}{l}\text { Goodman M, 2004, V23, P891, Polit } \\
\text { Geogr }\end{array}$ & $\begin{array}{l}\text { Reading fair trade: political ecological imaginary } \\
\text { and the moral economy of fair trade foods }\end{array}$ & 79 & 171 \\
\hline Gereffi G & 0 & 152 & Nicholls A, 2005, Fair Trade Market Dr & Fair Trade: Market-Driven Ethical Consumption & 74 & - \\
\hline Nicholls A & 74 & 151 & $\begin{array}{l}\text { Renard M, 2005, V21, P419, J Rural } \\
\text { Stud }\end{array}$ & $\begin{array}{l}\text { Quality certification, regulation and power in fair } \\
\text { trade }\end{array}$ & 71 & 120 \\
\hline Mutersbaugh T & 347 & 143 & $\begin{array}{l}\text { Loureiro M, 2005, V53, P129, Ecol } \\
\text { Econ }\end{array}$ & $\begin{array}{l}\text { Do fair trade and eco-labels in coffee wake up } \\
\text { the consumer conscience? }\end{array}$ & 70 & 132 \\
\hline SHAW D & 64 & 132 & Moore G, 2004, V53, P73, J Bus Ethics & $\begin{array}{l}\text { The Fair Trade Movement: Parameters, Issues } \\
\text { and Future Research }\end{array}$ & 69 & 106 \\
\hline Taylor P & 289 & 132 & Taylor P, 2005, V33, P129, World Dev & $\begin{array}{l}\text { In the Market But Not of It: Fair Trade Coffee and } \\
\text { Forest Stewardship Council Certification as } \\
\text { Market-Based Social Change }\end{array}$ & 64 & 200 \\
\hline Lyon S & 83 & 125 & Raynolds L, 2007, Fair Trade Challenge & $\begin{array}{l}\text { Fair Trade: The Challenges of Transforming } \\
\text { Globalization }\end{array}$ & 61 & - \\
\hline Loureiro M & 29 & 116 & $\begin{array}{l}\text { Raynolds L, 2009, V37, P1083, World } \\
\text { Dev }\end{array}$ & $\begin{array}{l}\text { Mainstreaming Fair Trade Coffee: From } \\
\text { Partnership to Traceability }\end{array}$ & 55 & 92 \\
\hline Low W & 96 & 114 & Ponte S, 2002, V30, P1099, World Dev & $\begin{array}{l}\text { The 'Latte Revolution'? Regulation, Markets and } \\
\text { Consumption in the Global Coffee Chain }\end{array}$ & 51 & 179 \\
\hline Tallontire A & 56 & 113 & $\begin{array}{l}\text { Raynolds L, 2004, V16, P1109, Journal } \\
\text { Of International Development }\end{array}$ & $\begin{array}{l}\text { Fair Trade coffee: building producer capacity via } \\
\text { global networks }\end{array}$ & 50 & 117 \\
\hline Murray D & 256 & 109 & $\begin{array}{l}\text { Carrigan M, 2001, V18, P560, J } \\
\text { Consum Mark } \\
\end{array}$ & $\begin{array}{l}\text { The myth of the ethical consumer - do ethics } \\
\text { matter in purchase behaviour? }\end{array}$ & 49 & 395 \\
\hline Goodman M & 196 & 102 & $\begin{array}{l}\text { Renard M, 1999, V39, P484, Sociol } \\
\text { Ruralis }\end{array}$ & $\begin{array}{l}\text { The Interstices of Globalization: The Example of } \\
\text { Fair Coffee }\end{array}$ & 44 & 78 \\
\hline Goodman D & 0 & 96 & $\begin{array}{l}\text { Tallontire A, 2000, V10, P166, } \\
\text { Development In Practice }\end{array}$ & $\begin{array}{l}\text { Partnerships in fair trade: reflections from a case } \\
\text { study of Cafedirect }\end{array}$ & 43 & 197 \\
\hline Barrientos S & 49 & 96 & Barnett C, 2005, V37, P23, Antipode & $\begin{array}{l}\text { Consuming Ethics: Articulating the Subjects and } \\
\text { Spaces of Ethical Consumption }\end{array}$ & 43 & 225 \\
\hline Becchetti L & 58 & 94 & $\begin{array}{l}\text { Raynolds L, 2007, V24, P147, Agr Hum } \\
\text { Values }\end{array}$ & $\begin{array}{l}\text { Regulating sustainability in the coffee sector: A } \\
\text { comparative analysis of third-party } \\
\text { environmental and social certification initiatives }\end{array}$ & 42 & 105 \\
\hline
\end{tabular}


Table 5: reference co-citation analysis cluster composition

\begin{tabular}{|c|c|c|c|c|c|}
\hline CLUSTER 1 & citations & $\begin{array}{l}\text { co-citation } \\
\text { links }\end{array}$ & CLUSTER 2 & citations & $\begin{array}{l}\text { co-citation } \\
\text { links }\end{array}$ \\
\hline renard mc, 2003, j rural stud, v19, p87 & 97 & 814 & de pelsmacker $p, 2005$, j consum aff, v39, p363 & 97 & 539 \\
\hline raynolds It, 2002, sociol ruralis, v42, p404 & 88 & 789 & loureiro $\mathrm{ml}, 2005$, ecol econ, v53, p129 & 70 & 396 \\
\hline raynolds It, 2000, agriculture and human values, v17, p297 & 86 & 765 & low w, 2005, int market rev, v22, p494 & 31 & 336 \\
\hline renard mc, 2005, j rural stud, v21, p419 & 71 & 728 & carrigan $\mathrm{m}, 2001$, j consum mark, v18, p560 & 49 & 335 \\
\hline goodman mk, 2004, polit geogr, v23, p891 & 79 & 590 & hira $a, 2006$, j bus ethics, v63, p107 & 29 & 288 \\
\hline taylor pl, 2005, world dev, v33, p129 & 63 & 551 & shaw d., 1999, marketing intelligen, v17, p109 & 34 & 275 \\
\hline renard mc, 1999, sociol ruralis, v39, p484 & 44 & 440 & davies ia, 2003, j bus ethics, v45, p79 & 22 & 270 \\
\hline Iyon s., 2006, Int J Consum Stud, v30, p452 & 37 & 394 & nicholls a. j., 2002, int j retail distrib, v30, p6 & 29 & 243 \\
\hline guthman j, 2007, antipode, v39, p456 & 40 & 358 & doran cj, 2009, j bus ethics, v84, p549 & 35 & 242 \\
\hline raynolds It, 2004, world dev, v32, p725 & 35 & 339 & bird k., 1997, business ethics euro, v6, p159 & 28 & 239 \\
\hline mutersbaugh t, 2005, j rural stud, v21, p389 & 33 & 338 & strong c., 1996, marketing intelligen, v14, p5 & 24 & 237 \\
\hline hudson i, 2003, organ environ, v16, p413 & 41 & 337 & shiu e., 2003, eur j marketing, v37, p1485 & 30 & 236 \\
\hline barham e., 2002, agr human values, v19, p349 & 27 & 314 & $\begin{array}{l}\text { ozcaglar-toulouse n., 2006, Int J Consum Stud, } \\
\text { v30, p502 }\end{array}$ & 26 & 232 \\
\hline bryant rl, 2004, t i brit geogr, v29, p344 & 35 & 301 & de pelsmacker $p, 2007, \mathrm{j}$ bus ethics, v75, p361 & 32 & 229 \\
\hline barnett c, 2005, antipode, v37, p23 & 42 & 286 & arnot c, 2006, can j agr econ, v54, p555 & 36 & 221 \\
\hline mutersbaugh t, 2002, environ plann a, v34, p1165 & 25 & 280 & ajzen i, 1991, organ behav hum dec, v50, p179 & 32 & 204 \\
\hline ponte s, 2005, econ soc, v34, p1 & 32 & 264 & shiu e, 2000 , j marketing manageme, v16, p879 & 22 & 198 \\
\hline bacon $\mathrm{cm}, 2010$, j peasant stud, v37, p111 & 31 & 259 & auger $p, 2003, j$ bus ethics, v42, p281 & 28 & 178 \\
\hline micheletti m, 2003, political virtue and shopping: $\mathrm{p} 1$ & 39 & 247 & chatzidakis a, 2007, j bus ethics, v74, p89 & 32 & 173 \\
\hline jaffee d, 2010, agr hum values, v27, p387 & 23 & 226 & $\begin{array}{l}\text { de pelsmacker p. d., 2006, int j nonprofit volu, } \\
\text { v11, p125 }\end{array}$ & 23 & 161 \\
\hline murdoch j, 2000, econ geogr, v76, p107 & 23 & 224 & vermeir i, 2006, j agr environ ethic, v19, p169 & 33 & 159 \\
\hline whatmore s., 1997, globalising food, p287 & 30 & 224 & auger $p, 2007, j$ bus ethics, v76, $p 361$ & 21 & 147 \\
\hline mutersbaugh t, 2005, environ plann a, v37, p2033 & 25 & 209 & browne aw, 2000, food policy, v25, p69 & 21 & 147 \\
\hline wright c., 2004, J. Int. Dev., v16, p665 & 22 & 208 & andorfer va, 2012, j bus ethics, v106, p415 & 23 & 129 \\
\hline freidberg s, 2003, soc cult geogr, v4, p27 & 21 & 200 & de ferran $f, 2007$, food qual prefer, v18, p218 & 21 & 117 \\
\hline guthman j, 2004, cal stud crit hum ge, v11, p1 & 26 & 194 & & & \\
\hline bourdieu pierre, 1984 , distinction social c & 21 & 179 & & & \\
\hline dolan cs, 2010, geoforum, v41, p33 & 21 & 179 & & & \\
\hline cashore b., 2004, governing markets fo & 21 & 168 & & & \\
\hline clarke $n, 2007$, polit geogr, v26, p231 & 21 & 159 & & & \\
\hline
\end{tabular}


Table 5 (continuation): reference co-citation analysis cluster composition

\begin{tabular}{|c|c|c|c|c|c|}
\hline CLUSTER 3 & citations & $\begin{array}{c}\text { co- } \\
\text { citation } \\
\text { links }\end{array}$ & CLUSTER 4 & citations & $\begin{array}{c}\text { co-citation } \\
\text { links }\end{array}$ \\
\hline bacon c, 2005, world dev, v33, p497 & 116 & 889 & nicholls a., 2005, fair trade market $d r$ & 74 & 605 \\
\hline jaffee d, 2007, brewing justice: fair trade coffee & 106 & 818 & moore $\mathrm{g}, 2004, \mathrm{j}$ bus ethics, v53, p73 & 69 & 513 \\
\hline raynolds I. t., 2004, j. int. dev. , v16, p1109 & 50 & 600 & raynolds I. t., 2007, fair trade challenge & 61 & 524 \\
\hline raynolds It, 2009, world dev, v37, p1083 & 55 & 513 & tallontire a., 2000, dev pract, v10, p166 & 43 & 393 \\
\hline ponte s, 2002, world dev, v30, p1099 & 51 & 434 & [anonymous], 2007, fair trade coffee pr & 43 & 375 \\
\hline murray d. I., 2006, development in practice, v16, p179 & 34 & 393 & low w, 2005, sustain dev, v13, p143 & 37 & 372 \\
\hline raynolds It, 2007, agr hum values, v24, p147 & 42 & 364 & barratt brown michael, 1993, fair trade reform & 28 & 291 \\
\hline gereffi $g, 2005$, rev int polit econ, v12, p78 & 41 & 349 & shreck a, 2005, agr hum values, v22, p17 & 29 & 289 \\
\hline taylor pl, 2005, sustain dev, v13, p199 & 29 & 330 & leclair ms, 2002, world dev, v30, p949 & 32 & 277 \\
\hline valkila j, 2009, ecol econ, v68, p3018 & 41 & 325 & levi m, 2003, polit soc, v31, p407 & 28 & 267 \\
\hline rice ra, 2001, j agr environ ethic, v14, p39 & 32 & 293 & reed $d, 2009, j$ bus ethics, v86, p3 & 30 & 262 \\
\hline arnould ej, 2009, j public policy mark, v28, p186 & 30 & 284 & murray d. I., 2000, agr hum values, v17, p65 & 28 & 254 \\
\hline bray db, 2002, soc natur resour, v15, p429 & 30 & 282 & jaffee d, 2004, rural sociol, v69, p169 & 34 & 250 \\
\hline calo m., 2005 , revaluing peasant co & 30 & 273 & renard m.-c., 2007, fair trade challenge, p138 & 23 & 248 \\
\hline daviron b. t., 2005, coffee paradox globa & 27 & 256 & low w., 2006, j strategic marketin, v14, p315 & 27 & 226 \\
\hline bacon cm, 2008, globalizations, v5, p259 & 31 & 253 & littrell m. a., 1999, social responsibilit & 28 & 208 \\
\hline murray d., 2003, one cup time poverty & 23 & 245 & moberg $\mathrm{m}, 2005$, hum organ, $\mathrm{v} 64, \mathrm{p} 4$ & 21 & 200 \\
\hline talbot jm, 2004, grounds agreement po & 22 & 231 & & & \\
\hline muradian r, 2005, world dev, v33, p2029 & 26 & 214 & & & \\
\hline giovannucci d, 2005, food policy, v30, p284 & 23 & 210 & & & \\
\hline becchetti I, 2008, world dev, v36, p823 & 23 & 183 & & & \\
\hline mendez ve, 2010 , renew agr food syst, v25, p236 & 27 & 179 & & & \\
\hline
\end{tabular}

